\title{
SPEKTRUM OPERATOR LAPLACE DISKRET PADA GRAF TORUS
}

\author{
ARNASLI YAHYA $^{1 *}$, YUdi SOEHARYADI ${ }^{1}$ \\ ${ }^{1}$ Kelompok Keilmuan Analisis dan Geometri, Fakultas Matematika dan Ilmu Pengetahuan Alam, \\ Institut Teknologi Bandung \\ *arnasli@math.itb.ac.id
}

\begin{abstract}
ABSTRAK
Spektrum operator laplace pada graf dapat diperoleh melalui analisis matriks laplacian, yakni dengan mempelajari persamaan karakteristik dan mencari ruang eigen untuk setiap nilai eigen yang diperoleh, namun cara ini tidak selalu mudah khususnya untuk kasus graf yang berukuran besar. Pada makalah ini, graf torus dipandang sebagai graf periodik. Melalui pendefinisian fungsi pada tiap verteks dan pendefinisian operator laplace, diperoleh formulasi masalah nilai eigen pada setiap verteks. Observasi dilakukan pada beberapa graf torus antara lain, graf lattice persegi panjang, lattice segitiga, dan lattice segienam. Rumus umum eksplisit nilai eigen laplacian graf lattice turus dari masing-masing graf berhasil diperoleh melalui observasi ini.
\end{abstract}

Kata kunci: Graf Torus, Lattice, Nilai Eigen, Operator Laplace Diskret

\begin{abstract}
The Spectrum of Laplace Operators on graphs could be obtained directly from the Laplacian matrix analysis, by analyzing the characteristic polynomial and obtaining eigenspaces for each eigenvalue. Unfortunately, this method might be complicated, particularly in large graphs including the large toroidal graphs. In this paper, we consider the toroidal graphs as periodic graphs. By defining functions at each vertex and defining Laplace operators, the eigenvalue problem formulation is defined at each vertex. We observe several toroidal graphs; rectangular lattice graph, triangular lattice, and hexagonal lattice. The explicit formula for the eigenvalue of each lattice graph was successfully obtained through this observation.
\end{abstract}

Keywords: Toroidal Graph, Lattice, Eigenvalues, Discrete Laplace Operator

\section{Pendahuluan}

Spektrum Graf merupakan topik yang cukup lama dipelajari dalam teori graf. Beberapa spektrum yang biasa dipelajari adalah spektrum ketetanggaan dan spektrum laplacian [1]. Analisis spektrum graf ini memiliki banyak kegunaan di berbagai bidang sains dan teknologi. Aplikasi dari analisis spektrum operator laplace pada graf ini diantaranya untuk melihat sifat geometris dari sebuah

2020 Mathematics Subject Classification: 05C50

Tanggal masuk: 16-03-20; direvisi: 29-04-20; diterima: 29-04-20. 
jaringan, kaitannya dengan konstanta Cheeger [2], spektral gap[3, 4], untuk mempelajari analisis sinyal pada graf [5], serta untuk mempelajari beberapa fitur dari random walk pada graf yang melalui matriks transisi stokastik yang melibatkan matriks laplacian [6].

Graf torus, yang merupakan graf non planar, adalah graf yang melekat pada permukaan torus / bentuk donat, persisnya adalah graf yang "hanya" dapat digambarkan pada permukaan torus tanpa ada sisi yang berpotongan [7]. Beberapa cara untuk mendapatkan graf torus antara lain adalah: Triangulasi, Dekomposisi pita, dan Pelekatan graf pada permukaan, (Gambar 1 dan 2) [7]. Secara khusus torus merupakan permukaan bergenus 1, lebih lanjut karakterisasi dari pelekatan graf pada permukaan bergenus dapat diidentifikasi melalui rumus Euler [7]. Pada makalah ini, graf torus akan dipandang

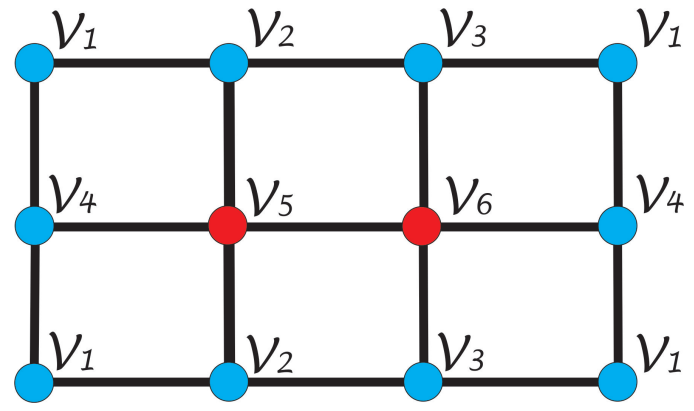

Gambar 1: Sebuah graf lattice

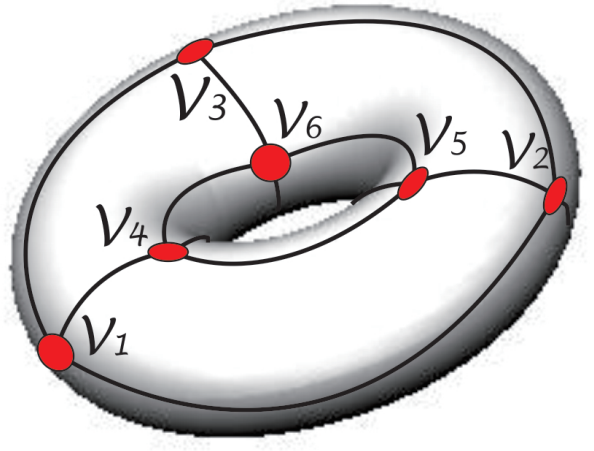

Gambar 2: Pelekatan graf lattice pada torus

sebagai graf periodik, seperti yang telah dilakukan oleh Peter John, dkk. [8], persisnya adalah sebagai berikut.

\subsection{Graf Periodik}

Definisi 1.1. Graf $G$ merupakan graf berperiode lipat 2 jika dan hanya jika terdapat dua buah translasi $T_{\boldsymbol{p}_{1}}$ dan $T_{\boldsymbol{p}_{2}}$ di bidang Euclid $\mathbb{E}^{2}$, yang direpresentasikan oleh vektor $\boldsymbol{p}_{1}$ and $\boldsymbol{p}_{2}$ yang bebas linear sedemikian sehingga graf G tidak berubah terhadap dua transformasi tersebut, khususnya $T_{\boldsymbol{p}_{1}} G$ dan $T_{\boldsymbol{p}_{2}} G$ isomorfik dengan $G$.

Pada definisi (1.1) ini, vektor $\mathbf{p}_{1}$ and $\mathbf{p}_{2}$ disebut sebagai pasangan periode dari graf periodik $G$. Berikut (Gambar 3), adalah contoh graf berperiode lipat 2. Salah satu konsekuensi dari pendefin-

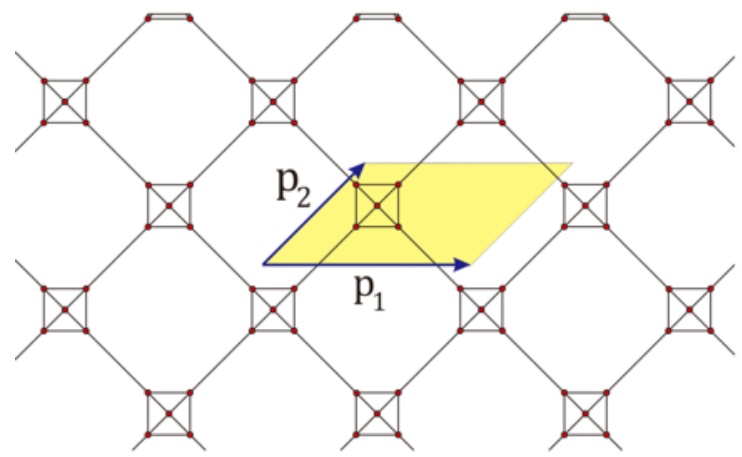

Gambar 3: Contoh graf berperiode lipat 2

isian ini adalah diperolehnya sistem koordinat yang dibangun oleh dua vektor $\mathbf{p}_{1}$ and $\mathbf{p}_{2}$, yang akan 
menjadi dasar pijakan analisis selanjutnya. Misalkan $\mathscr{C}$ adalah sistem koordinat pada bidang Euclid yang dibangun oleh $\mathbf{p}_{1}$ and $\mathbf{p}_{2}$, maka $\mathscr{C}$ akan menentukan "pengubinan" oleh jajaran genjang-jajaran genjang yang direntang oleh $\mathbf{p}_{1}$ and $\mathbf{p}_{2}$, (Gambar 4). Jajaran-jajaran genjang yang terbentuk ini dapat diidentifikasi melalui letak atau koordinat relatifnya terhadap basis $\left\{\mathbf{p}_{1}, \mathbf{p}_{2}\right\}$. Misalkan $P_{\mathbf{x}}$ adalah
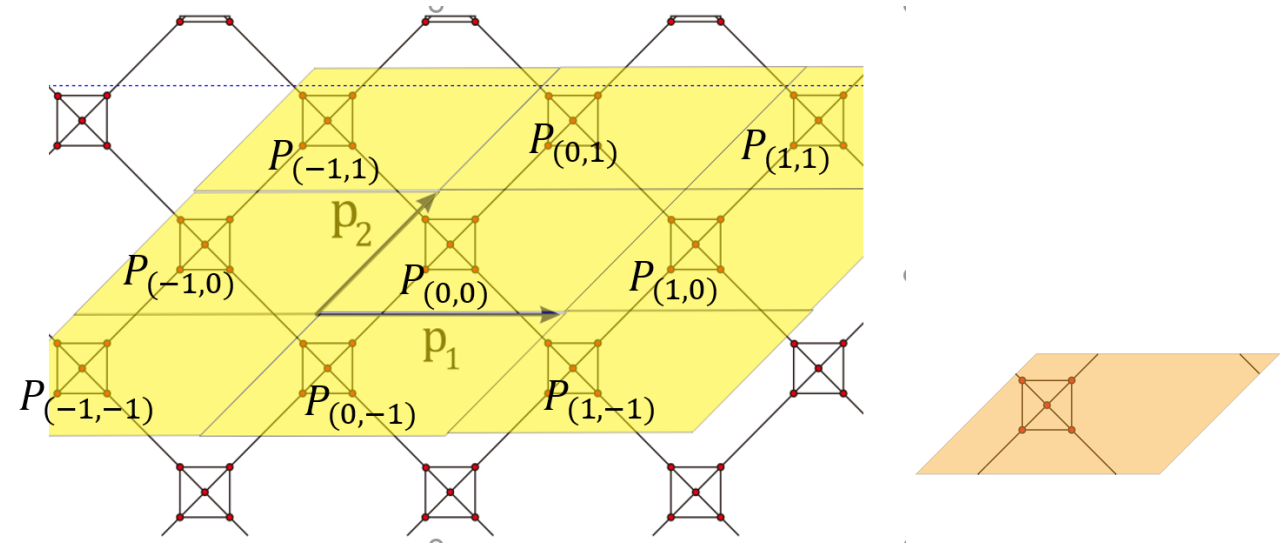

Gambar 4: Pengubinan oleh $\mathbf{p}_{1}$ and $\mathbf{p}_{2}$

Gambar 5: Jajaran genjang periode dasar

jajarangenjang dasar (ubin) yang dibangun oleh $\mathbf{p}_{1}, \mathbf{p}_{2}$ yang memiliki koordinat relatif $\mathbf{x}=\left(x_{1}, x_{2}\right)$ di $\mathscr{C}$, (Gambar 4). Dengan pengertian ini, disepakati bahwa $P_{\mathbf{0}}$ menyatakan jajaran genjang dasar (ubin) yang direntang oleh vektor $\mathbf{p}_{1}, \mathbf{p}_{2}$ dengan titik pangkal titik asal $O$. Dalam hal ini $P_{\mathbf{0}}$ mempunyai koordinat relatif $(0,0)$. Perhatikan bahwa graf $\mathrm{G}$ dapat diidentifikasi oleh bagian graf yang digambar pada $P_{\mathbf{0}}$, yang berarti keseluruhan informasi dari graf $\mathrm{G}$ dapat diwakili secara sempurna oleh graf di dalam $P_{\mathbf{0}}$ (Gambar 4 dan 5).

Gagasan ini dapat dinyatakan dalam definisi grid koordinat integer di bidang Euclid yang dibangun oleh $\mathbf{p}_{1}$ dan $\mathbf{p}_{2}$, persisnya didefinisikan $\mathbf{X}=\left\{x_{1} \mathbf{p}_{1}+x_{2} \mathbf{p}_{2} \mid x_{1}, x_{2} \in \mathbb{Z}\right\}$. Dari definisi ini, dapat dilihat bahwa $\mathbf{p}_{1}=(1,0)$ dan $\mathbf{p}_{2}=(0,1)$. Konsekuensi dari gagasan ini memunculkan pendefinisian hubungan kongruensi sebagai berikut.

Definisi 1.2. Dua titik $X, Y$ di bidang Euclid disebut kongruen modulo $\boldsymbol{p}_{1}$ dan $\boldsymbol{p}_{2}$, dinotasikan dengan $X \equiv Y \bmod \left(\boldsymbol{p}_{1}, \boldsymbol{p}_{2}\right)$, jika terdapat bilangan bulat $r_{1}, r_{2}$ sedemikian sehingga $X-Y=r_{1} \boldsymbol{p}_{1}+r_{2} \boldsymbol{p}_{2}$

Verteks-verteks dari $G$ yang tergambar pada jajaran genjang dasar $P_{\mathbf{0}}$ selanjutnya diberi nomor $1,2, \ldots, m$, dengan $m$ adalah banyaknya verteks pada $P_{\mathbf{0}}$. Hal ini diperlukan untuk mendefiniskan fungsi pada verteks graf ini nantinya. Dengan cara ini setiap verteks pada keseluruhan $\mathrm{G}$ dapat diidentifikasi melalui nomor verteks dan juga letak ubin $P_{x_{1}, x_{2}}$. Verteks $v\left(x_{1}, x_{2}, j\right)$ misalnya, adalah verteks yang terletak pada jajaran genjang dasar (ubin) $P_{\left(x_{1}, x_{2}\right)}$ dan kongruen dengan verteks $j$ (pada $\left.P_{\mathbf{0}}\right) \bmod \left(\mathbf{p}_{1}, \mathbf{p}_{2}\right)$, yakni $v\left(x_{1}, x_{2}, j\right) \equiv v(0,0, j) \bmod \left(\mathbf{p}_{1}, \mathbf{p}_{2}\right)$. Setelah pendefinisian graf berperiode lipat 2, akan dimulai untuk merekonstruksi graf yang melekat pada torus.

\subsection{Representasi Torus}

Pada makalah ini, Torus dibangun melalui sebuah "flat torus", yakni sebuah jajaran genjang yang diidentifikasi pada dua pasang sisi yang sejajar, dengan artian setiap titik pada sepasang sisi sejajarnya dipandang sama. Melalui gagasan ini, didefinisikan beberapa hal sebagai berikut. Misalkan $\mathbf{a}=\left[\begin{array}{l}a_{1} \\ a_{2}\end{array}\right]$ dan $\mathbf{b}=\left[\begin{array}{l}b_{1} \\ b_{2}\end{array}\right]$ dua vektor bebas linear dengan elemen bilangan bulat, persisnya $\mathbf{a}$ dan $\mathbf{b}$ dua ekspresi vektor yang menyatakan koordinat vektor relatif terhadap basis $\left\{\mathbf{p}_{1}, \mathbf{p}_{2}\right\}$.

Misalkan pula $A=\left[\begin{array}{ll}a_{1} & a_{2} \\ b_{1} & b_{2}\end{array}\right]$, dan $\triangle=|\operatorname{det}(A)|$, didefinisikan $\mathrm{P}(\mathrm{A})$ yang menyatakan sebuah jajaran genjang yang direntang oleh vektor a dan b, (gambar 6). Jelas bahwa luas jajaran genjang P(A) 


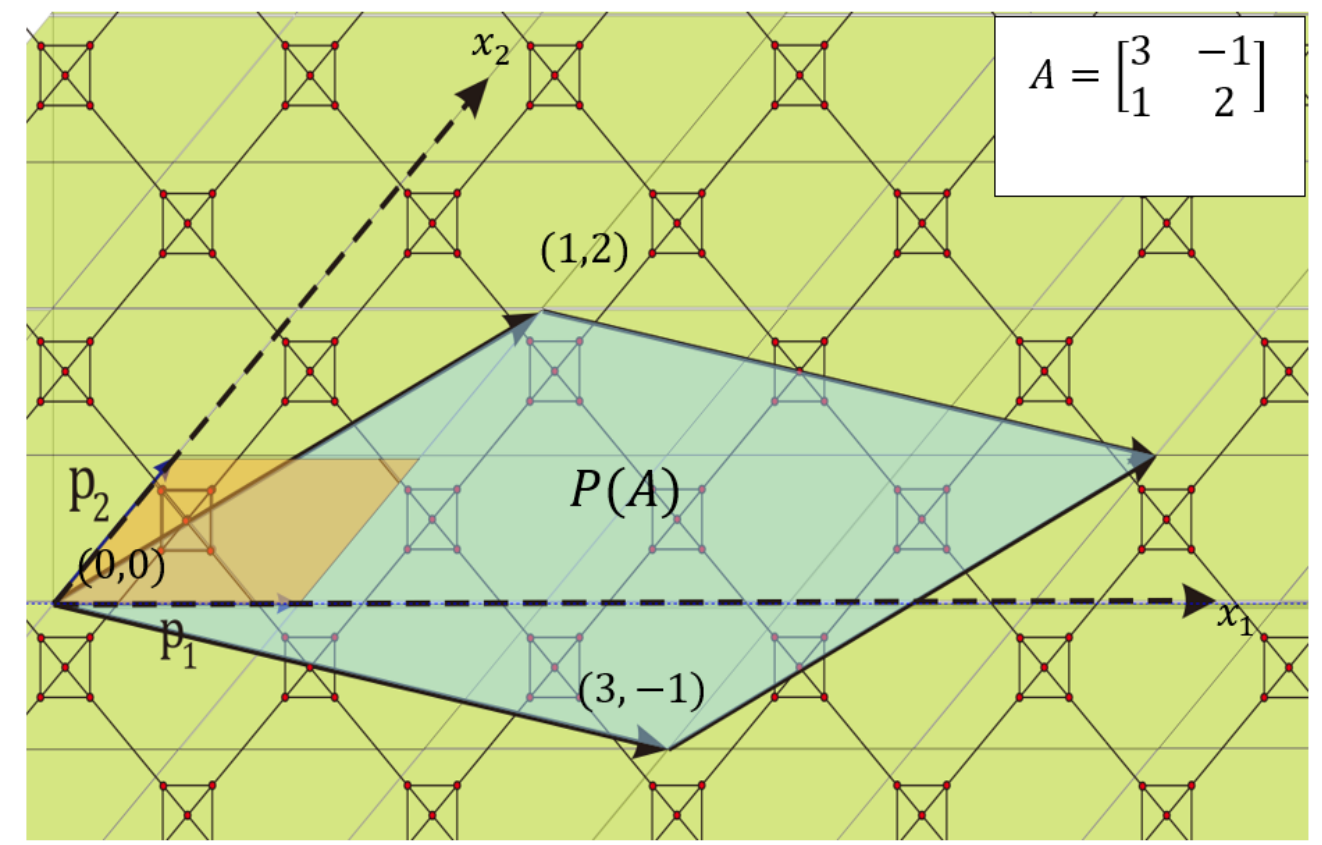

Gambar 6: Representasi Torus $P(A)$

ini adalah $\triangle$. Lemma 1.3 berikut menunjukkan bahwa graf yang dilingkupi oleh $P(A)$ merupakan sebuah graf torus. Oleh karenanya, untuk selanjutnya jajaran ganjang $P(A)$ juga menyatakan sebuah representasi torus.

Lemma 1.3. Jika $G$ graf berperiode lipat 2 dengan vektor periode $\boldsymbol{p}_{1}$ dan $\boldsymbol{p}_{2}$. Maka G juga berperiode lipat 2 dengan vektor periode $\boldsymbol{a}$ dan $\boldsymbol{b}$.

BUKTI. Tanpa mengurangi keumuman, misalkan $\mathbf{a}=\left[\begin{array}{l}a_{1} \\ a_{2}\end{array}\right]$, dengan $a_{1}$ dan $a_{2}$ bulat positif maka vektor a dapat dinyatakan dengan $\mathbf{a}=a_{1} \mathbf{p}_{1}+a_{2} \mathbf{p}_{2}$. Maka translasi dengan arah vektor $\mathbf{a}$ dapat dinyatakan dengan $T_{\mathbf{a}}=T_{\left(a_{1} \mathbf{p}_{1}+a_{2} \mathbf{p}_{2}\right)}=T_{\left(a_{1} \mathbf{p}_{1}\right)} \circ T_{\left(a_{2} \mathbf{p}_{2}\right)}=\left(T_{\mathbf{p}_{1}}\right)^{a_{1}} \circ\left(T_{\mathbf{p}_{2}}\right)^{a_{2}}$. Dengan demikian $T_{\mathbf{a}} G=$ $\left(T_{\mathbf{p}_{1}}\right)^{a_{1}} \circ\left(T_{\mathbf{p}_{2}}\right)^{a_{2}} G=G$. Dengan cara serupa dapat ditunjukkan juga bahwa $T_{\mathbf{b}} G=G$.

Perlu diperhatikan bahwa luas jajaran genjang $P(A)$ di sini adalah $\triangle$ kali luas jajaran genjang dasar $P_{\mathbf{0}}$.

\section{Masalah Nilai Eigen}

Pertama-tama didefinisikan fungsi $f: V \rightarrow \mathbb{C}$ pada verteks graf G. Misalkan $\mathscr{L}$ adalah operator laplace, maka permasalahan nilai eigen dapat dituliskan dengan $\mathscr{L} f=\lambda f$, dengan syarat batas periodik (torus). Melalui persamaan beda hingga dengan grid lattice sederhana, dan menerapkan ekspansi Taylor, dapat diperoleh fakta bahwa operator $\mathscr{L}$ dapat direpresentasikan dengan matriks laplace [3]. Pendefinisian operator laplace ternormaliasasi akan menghasilkan formulasi masalah nilai eigen pada setiap verteks $v$ sebagai berikut

$$
f(v)-\sum_{v^{\prime} \in N(v)} \frac{1}{\sqrt{d\left(v^{\prime}\right) d(v)}} f\left(v^{\prime}\right)=\lambda f(v)
$$

dengan $d(v)$ menyatakan derajat verteks $v$, dan $N(v)$ menyatakan "neighborhood" verteks $v$, yakni himpunan verteks yang terhubung dengan $v$. Syarat batas torus ditentukan oleh jajaran genjang $P(A)$. 
Jika persamaan (1) ditulis secara lengkap secara menurun untuk setiap verteks $1,2, \ldots, m$ maka akan diperoleh masalah nilai eigen yang biasa dinyatakan melalui ekspresi yang melibatkan matriks Laplace ternormalisasi. Masalah ini dapat diselesaikan dengan menggunakan persamaan karakteristik. Meskipun demikian, cara ini bisa menjadi rumit untuk kasus graf berukuran besar.

Selanjutnya, permasalahan pada batas torus $P(A)$ diselesaikan melalui sebuah trik, yang dikembangkan oleh Peter John [8], sebagai berikut. Untuk setiap verteks $v\left(x_{1}, x_{2}, j\right)$ pada $\mathrm{G}$ diberikan Ansatz:

$$
\varphi\left(v\left(x_{1}, x_{2}, j\right)\right)=\rho_{1}{ }^{x_{1}} \rho_{2}{ }^{x_{2}} u_{j}
$$

dengan $\rho_{1}, \rho_{2}$ bilangan kompleks, dan $u_{j}$ sebuah nilai. Kembali ke representasi torus $P(A)$, titik $(0,0),\left(a_{1}, a_{2}\right)$ dan $\left(b_{1}, b_{2}\right)$ merepresentasikan titik yang sama pada permukaan torus. Oleh karenanya, nilai fungsi pada titik-titik tersebut haruslah sama.

Dengan gagasan tersebut, melalui ansatz (2), diperoleh persamaan

$$
\rho_{1}{ }^{a_{1}} \rho_{2}{ }^{a_{2}}=\rho_{1}{ }^{b_{1}} \rho_{2}{ }^{b_{2}}=1 \text {. }
$$

Persamaan (3) disebut sebagai persamaan kunci terkait dengan representasi torus $P(A)$. Solusi persamaan kunci merupakan sepasang bilangan kompleks yang memenuhi $\rho_{1} \triangle=\rho_{2}{ }^{\triangle}=1$. Lebih jauh lagi, solusi (3) terdiri dari tepat $\triangle$ pasang bilangan kompleks yang selanjutnya himpunan solusi ini dinotasikan dengan $\mathbb{R}(A)$. Persisnya

$$
\mathbb{R}(A)=\left\{\rho=\left(\rho_{1}, \rho_{2}\right) \mid \rho_{1}{ }^{a_{1}} \rho_{2}{ }^{a_{2}}=\rho_{1}{ }^{b_{1}} \rho_{2}{ }^{b_{2}}=1\right\} .
$$

\subsection{Nilai Eigen dan Fungsi Eigen Laplace}

Misalkan $G$ adalah graf periodik dan $P(A)$ adalah jajaran genjang terkait matriks $A$, yang merepresentasikan sebuah torus, maka Graf torus dari $P(A)$ adalah bagian dari graf $G$ yang termuat di dalam $P(A)$, atau dapat dinyatakan sebagai $G(A)=G \cap P(A)$. Solusi dari masalah nilai eigen (1) dengan syarat batas torus $P(A)$ merupakan nilai-nilai eigen dan fungsi-fungsi eigen terkait. Solusi masalah nilai eigen ini diperoleh melalui prosedur sederhana sebagai berikut. Prosedur ini diadaptasi dari metode yang dibangun oleh John(2009) dalama menyelesaiakan masalah nilai eigen ketetanggaan [8].

1. Setiap solusi dari persamaan kunci (4) disubtitusikan ke ansatz (2) maka akan diperoleh sebuah fungsi periodik.

2. Fungsi periodik ini disubtitusikan ke masalah nilai eigen laplacian persamaan (1).

3. Menentukan semua nilai eigen dari persamaan (1)

4. Mendapatkan fungsi eigen terkait dengan terkait masing-masing nilai eigen dengan melihat kembali fungsi periodik yang diperoleh dari langkah 1.

Nilai eigen $\lambda$ yang diperoleh akan bergantung pada pemilihan $\rho \in \mathbb{R}(A)$. Banyaknya verteks $v$ pada jajaran genjang dasar $P_{\mathbf{0}}$ juga mempengaruhi banyaknya nilai eigen yang diperoleh. Jika $P_{\mathbf{0}}$ memuat $m$ buah verteks, maka didapat $m$ buah persamaan masalah nilai eigen. Apabila dituliskan secara berurutan dapat terbentuk persamaan yang melibatkan matriks Laplacian berukuran $m \times m$, yang mempunyai $m$ buah nilai eigen.

Oleh karenanya, seperti yang dilakukan oleh John (2009) [8], nilai eigen yang diperoleh dapat ditulis $\lambda=\lambda(j, \rho)$, dengan $\rho \in \mathbb{R}(A)$ dan $j=1,2, \cdots, m$.

Fungsi eigen terkait $\lambda(j, \rho)$ ditulis dengan $f_{(j, \rho)}$, yang mana nilai di setiap titik $v=v\left(x_{1}, x_{2}, j\right)$ adalah $f_{(j, \rho)}\left(x_{1}, x_{2}, j\right)=\rho_{1}^{x_{1}} \rho_{2}^{x_{2}} u_{j}$. Fungsi-fungsi eigen ini membentuk himpunan orthogonal. Sebelum membahas fakta orthogonalitas fungsi eigen, diperlukan lemma (2.1), (2.2) dan (2.3) sebagai berikut. 
Lemma 2.1. Himpunan $\mathbb{R}(A)$ dengan operasi perkalian $\left(\rho_{1}, \rho_{2}\right)\left(\sigma_{1}, \sigma_{2}\right)=\left(\rho_{1} \sigma_{1}, \rho_{2} \sigma_{2}\right)$ membentuk sebuah grup abelian

Dapat ditunjukkan dengan mudah bahwa operasi perkalian ini tertutup, asosiatif, komutatif. Elemen $I=(1,1) \in \mathbb{R}(A)$ merupakan identitas perkalian dan juga setiap $\left(\rho_{1}, \rho_{2}\right)$ di $\mathbb{R}(A)$ memiliki invers $\left(\overline{\rho_{1}}, \overline{\rho_{2}}\right)$. Lemma ini akan berguna untuk menunjukkan bahwa pendefinisian masalah nilai eigen pada persamaan (1) berhasil membentuk spektrum lengkap yang orthogonal.

Lemma 2.2 menjelaskan sifat-sifat $\left(\rho_{1}, \rho_{2}\right) \in \mathbb{R}(A)$ terkait dengan jajaran genjang $P(A)$. Selanjutnya, didefinisikan $X(A)=\mathbf{X} \cap P(A)$ yakni semua koordinat $\mathbf{X}$ yang termuat dalam jajaran genjang $P(A)$.

Lemma 2.2. Untuk sembarang $\left(\rho_{1}, \rho_{2}\right) \in \mathbb{R}(A)$ berlaku

$$
\sum_{x \in \boldsymbol{X}(A)} \rho_{1}^{x_{1}} \rho_{2}^{x_{2}}=\left\{\begin{array}{l}
\triangle, \text { untuk } \rho_{1}=\rho_{2}=1 \\
0, \text { untuk yang lain }
\end{array} .\right.
$$

BUKTI. Pertama-tama, misalkan $\Gamma$ adalah grid yang dibangun oleh $\mathbf{a}=\left[\begin{array}{l}a_{1} \\ a_{2}\end{array}\right]$ dan $\mathbf{b}=\left[\begin{array}{l}b_{1} \\ b_{2}\end{array}\right]$. Selanjutnya pada grid ini, pandang $\mathbf{p}=\left[\begin{array}{l}\triangle \\ 0\end{array}\right]$ dan $\mathbf{q}=\left[\begin{array}{l}0 \\ \triangle\end{array}\right]$, (gambar 7). Tanpa mengurangi keumuman, misalkan $\operatorname{det}(A)>0$, dengan kata lain $\triangle=\operatorname{det}(A)=a_{1} b_{2}-b_{1} a_{2}$. Dengan demikian vektor $\mathbf{p}$ dan $\mathbf{q}$ dapat ditulis sebagai berikut

$$
\begin{aligned}
& \mathbf{p}=\left[\begin{array}{c}
a_{1} b_{2}-b_{1} a_{2} \\
0
\end{array}\right]=b_{2}\left[\begin{array}{l}
a_{1} \\
a_{2}
\end{array}\right]-b_{2}\left[\begin{array}{l}
b_{1} \\
b_{2}
\end{array}\right]=b_{2} \mathbf{a}-a_{2} \mathbf{b} \\
& \mathbf{q}=\left[\begin{array}{c}
0 \\
a_{1} b_{2}-b_{1} a_{2}
\end{array}\right]=a_{1}\left[\begin{array}{l}
b_{1} \\
b_{2}
\end{array}\right]-b_{1}\left[\begin{array}{l}
a_{1} \\
a_{2}
\end{array}\right]=a_{1} \mathbf{b}-b_{1} \mathbf{a} .
\end{aligned}
$$

Jika titik-titik yang kongruen $\bmod (\mathbf{p}, \mathbf{q})$ dipandang ekivalen, persegi $Q$ yang direntang oleh $\mathbf{p}$ dan q dengan luas $\triangle^{2}$, setelah silih bertukar daerah, persegi $Q$ dapat melingkupi daerah yang luasnya sebanyak $\triangle$ buah jajaran genjang $P(A)$, (gambar 8). Sejumlah $\triangle$ jajaran genjang yang masingmasing kongruen dengan $P(A)$ ini selanjutnya dinamai $P_{1}=P(A), P_{2}, \ldots, P_{\triangle}$. Untuk setiap $\left(\rho_{1}, \rho_{2}\right) \in$ $\mathbb{R}(A)$, fungsi $\varphi\left(x_{1}, x_{2}\right)=\rho_{1}{ }^{x_{1}} \rho_{2}{ }^{x_{2}}$ berperiode $(\mathbf{a}, \mathbf{b})$ dan juga $(\mathbf{p}, \mathbf{q})$. Hal ini dapat dilihat dalam persamaan berikut

$$
\varphi\left(\mathbf{x}+\alpha_{1} \mathbf{p}+\alpha_{2} \mathbf{q}\right)=\rho_{1}{ }^{x_{1}+\alpha_{1} \triangle} \rho_{2}{ }^{x_{2}+\alpha_{2} \triangle}=\rho_{1}{ }^{x_{1}} \rho_{2}{ }^{x_{2}}\left(\rho_{1} \triangle\right)^{\alpha_{1}}\left(\rho_{2}{ }^{\triangle}\right)^{\alpha_{2}}=\rho_{1}{ }^{x_{1}} \rho_{2}{ }^{x_{2}}=\varphi(\mathbf{x}) .
$$

Dengan demikian

$$
\sum_{\mathbf{x} \in \mathbf{X} \cap Q} \rho_{1}^{x_{1}} \rho_{2}{ }^{x_{2}}=\sum_{i=1}^{\triangle} \sum_{\mathbf{x} \in \mathbf{X} \cap P_{i}} \rho_{1}^{x_{1}} \rho_{2}{ }^{x_{2}}=\triangle \sum_{\mathbf{x} \in \mathbf{X}(A)} \rho_{1}^{x_{1}} \rho_{2}{ }^{x_{2}}
$$

Dengan kata lain

$$
\sum_{\mathbf{x} \in \mathbf{X} \cap Q} \rho_{1}{ }^{x_{1}} \rho_{2}{ }^{x_{2}}=\sum_{x_{1}=0}^{\triangle-1} \sum_{x_{2}=0}^{\triangle-1} \rho_{1}^{x_{1}} \rho_{2}{ }^{x_{2}}=\sum_{x_{1}=0}^{\triangle-1} \rho_{1}{ }^{x_{1}} \sum_{x_{2}=0}^{\triangle-1} \rho_{2}{ }^{x_{2}}=\left\{\begin{array}{l}
\triangle^{2}, \text { untuk } \rho_{1}=\rho_{2}=1 \\
0, \text { untuk yang lainnya }
\end{array}\right.
$$

Lemma 2.3. Untuk setiap $\left(\rho_{1}, \rho_{2}\right),\left(\sigma_{1}, \sigma_{2}\right) \in \mathbb{R}(A)$ berlaku

$$
\sum_{x \in \boldsymbol{X}(A)} \rho_{1}^{x_{1}} \rho_{2}{ }^{x_{2}} \sigma_{1}{ }^{-x_{1}} \sigma_{2}{ }^{-x_{2}}=\left\{\begin{array}{l}
\triangle, \text { untuk }\left(\rho_{1}, \rho_{2}\right)=\left(\sigma_{1}, \sigma_{2}\right) \\
0, \text { untuk yang lainnya } .
\end{array}\right.
$$




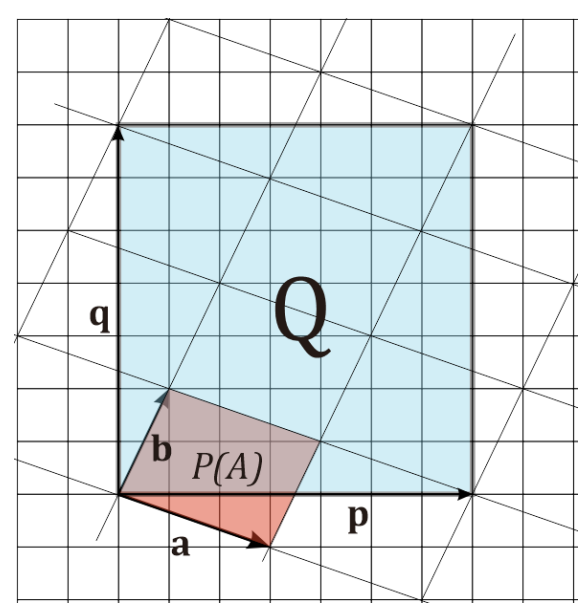

Gambar 7: Persegi Q dengan panjang sisi $\triangle$

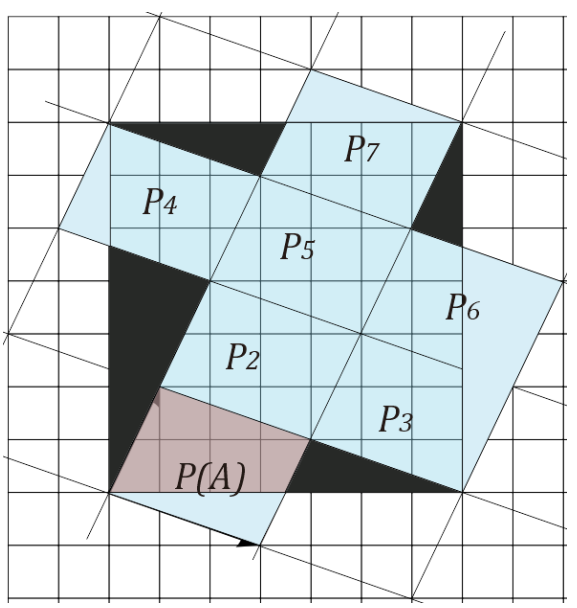

Gambar 8: Luas persegi $Q$ sama dengan $\triangle$ kali dari luas $P(A)$

\section{BUKTI.}

Menurut lemma (2.1), $\mathbb{R}(A)$ dengan operasi perkalian seperti yang telah didefinisikan membentuk grup abelian. Oleh karenanya, $\left(\rho_{1}, \rho_{2}\right)\left(\bar{\sigma}_{1}, \bar{\sigma}_{2}\right) \in \mathbb{R}(A)$.

Menurut lemma (2.2)

$$
\sum_{x \in \mathbf{X}(A)} \rho_{1}^{x_{1}} \rho_{2}^{x_{2}}=\left\{\begin{array}{l}
\triangle \text {. untuk } \rho_{1}=\rho_{2}=1 \\
0, \text { untuk yang lainnya }
\end{array}\right.
$$

Jadi

$$
\sum_{x \in \mathbf{X}(A)} \rho_{1}^{x_{1}} \rho_{2}^{x_{2}} \sigma_{1}^{-x_{1}} \sigma_{2}{ }^{-x_{2}}=\sum_{x \in \mathbf{X}(A)}\left(\rho_{1} \overline{\sigma_{1}}\right)^{x_{1}}\left(\rho_{2} \overline{\sigma_{2}}\right)^{x_{2}}=\left\{\begin{array}{l}
\triangle, \text { untuk }\left(\rho_{1}, \rho_{2}\right)=\left(\sigma_{1}, \sigma_{2}\right) \\
0, \text { untuk yang lainnya }
\end{array}\right.
$$

\subsection{Orthogonalitas Fungsi Eigen}

Kembali ke $m \triangle$ buah fungsi eigen yang diperoleh melalui prosedur yang telah diterapkan. Semua fungsi-fungsi eigen tersebut dapat dinyatakan sebagai berikut.

$$
f_{(\mu, \rho)}\left(x_{1}, x_{2}, j\right)=\rho_{1}{ }^{x_{1}} \rho_{2}{ }^{x_{2}} u_{j}(\mu, \rho)
$$

dengan $\rho \in \mathbb{R}(A)$ dan $\mu=1,2, \cdots, m$

Teorema 2.4. Misalkan $G$ adalah graf berperiode lipat dua dan $G(A)$ adalah bagian graf $G$ yang terletak representasi torus pada $P(A)$. Misalkan pula $f_{(\mu, \rho)}$ adalah fungsi eigen yang terkait dengan nilai eigen $\lambda(\mu, \rho)$. Maka fungsi-fungsi eigen ini membentuk himpunan orthogonal, yakni

$$
\left\langle f_{(\mu, \rho)}, f_{(\eta, \sigma)}\right\rangle=\left\{\begin{array}{l}
\triangle\|u(\mu)\|_{P_{0}}^{2}, \text { untuk } \mu=\eta, \rho=\sigma \\
0, \text { untuk yang lainnya }
\end{array}\right.
$$


BukTi. Ambil $\mu, \eta=1,2, \cdots, m$ dan $\rho, \sigma \in \mathbb{R}(A)$

$$
\begin{aligned}
\left\langle f_{(\mu, \rho)}, f_{(\eta, \sigma)}\right\rangle & =\sum_{\mathbf{x} \in \mathbf{X}(A), j \in[m]} f_{(\mu, \rho)}\left(x_{1}, x_{2}, j\right) \overline{f_{(\eta, \sigma)}\left(x_{1}, x_{2}, j\right)} \\
& =\sum_{\mathbf{x} \in \mathbf{X}(A), j \in[m]} \rho_{1}^{x_{1}} \rho_{2}{ }^{x_{2}} u_{j}(\mu, \rho) \overline{\sigma_{1}{ }^{x_{1}} \sigma_{2}{ }^{x_{2}} u_{j}(\eta, \sigma)} \\
& =\sum_{\mathbf{x} \in \mathbf{X}(A), j \in[m]}\left(\rho_{1} \overline{\sigma_{1}}\right)^{x_{1}}\left(\rho_{2} \bar{\sigma}_{2}\right)^{x_{2}} u_{j}(\mu, \rho) \overline{u_{j}(\eta, \sigma)} \\
& =\sum_{j \in[m]} u_{j}(\mu, \rho) \overline{u_{j}(\eta, \sigma)} \sum_{\mathbf{x} \in \mathbf{X}(A)}\left(\rho_{1} \overline{\sigma_{1}}\right)^{x_{1}}\left(\rho_{2} \overline{\sigma_{2}}\right)^{x_{2}}
\end{aligned}
$$

Menurut lemma (2.3) Ekspresi $\sum_{\mathbf{x} \in \mathbf{X}(A)}\left(\rho_{1} \bar{\sigma}_{1}\right)^{x_{1}}\left(\rho_{2} \bar{\sigma}_{2}\right)^{x_{2}}$ mempunyai nilai $\triangle$ jika $\rho=\sigma$, dan 0 untuk kasus yang lainnya. Dengan demikian, khusus untuk situasi $\rho=\sigma$ diperoleh kesamaan berikut

$$
\begin{aligned}
\left\langle f_{(\mu, \rho)}, f_{(\eta, \sigma)}\right\rangle & =\triangle \sum_{j \in[m]} u_{j}(\mu, \rho) \overline{u_{j}(\eta, \sigma)} \\
& =\left\{\begin{array}{l}
\triangle\|u(\mu)\|_{P_{0}}^{2}, \text { untuk } \mu=\eta \\
0, \text { untuk yang lainnya }
\end{array}\right.
\end{aligned}
$$

\section{Observasi pada Graf Lattice Torus}

Metode yang dibangun pada sub bab (2.1) dapat dilakukan pada sembarang graf periodik, dengan sembarang representasi torus $P(A)$. Pada sub bab berikutnya, akan dibahas kelas graf torus khusus, yakni graf lattice, yang meliputi graf lattice persegipanjang, lattice segitiga, dan lattice segienam. Pada akhir subbab akan dibahas, perbandingan nilai eigen dari masing-masing graf lattice tersebut.

\subsection{Lattice Persegipanjang}

Lattice persegi panjang dapat diperoleh melalui diskretisasi dan de-ngan menerapkan metode beda hingga biasa pada sebuah flat torus. Masalah nilai eigen di setiap verteks $v$ dapat dirumuskan

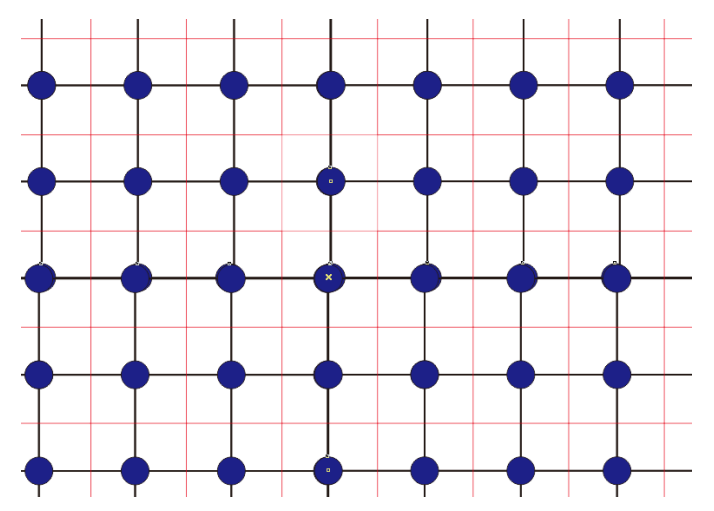

Gambar 9: Lattice Persegipanjang 
sebagai berikut

$$
f(v)-\sum_{v^{\prime} \in N(v)} \frac{1}{4} f\left(v^{\prime}\right)=\lambda f(v), \quad v \in V .
$$

Dengan melakukan subtitusi ansatz $f\left(x_{1}, x_{2}, j\right)=\rho_{1}{ }^{x_{1}} \rho_{2}{ }^{x_{2}} u_{j}$ pada persamaan (8) diperoleh nilai $\lambda=1-\frac{1}{4}\left(\rho_{1}+\overline{\rho_{1}}+\rho_{2}+\overline{\rho_{2}}\right)$. Selanjutnya, misalkan dipilih representasi torus $P(A)$ dengan $A=$ $\left[\begin{array}{cc}m & 0 \\ 0 & n\end{array}\right]$. Pemilihan $A$ ini akan memberikan graf dari bentuk triangulasi torus sederhana seperti pada gambar 9. Persamaan kunci terkait dengan representasi torus $P(A)$ adalah sebagai berikut

$$
\rho_{1}^{m} \rho_{2}^{0}=\rho_{1}^{0} \rho_{2}^{n}=1 .
$$

Persamaan kunci ini mempunyai solusi $\mathbb{R}(A)=\left\{\left(e^{\frac{2 \pi i j}{m}}, e^{\frac{2 \pi i k}{n}}\right) \mid j=0,1,2, \ldots, m-1, k=0,1,2, \ldots, n-1\right\}$ Dengan melakukan subtitusi setiap nilai di $\mathbb{R}(A)$ ke persamaan $\lambda$ didapatkan nilai-nilai eigen graf lattice persegipanjang pada torus $P(A)$, sebagai berikut

$$
\lambda_{(j, k)}=1-\frac{1}{2} \cos \left(\frac{2 \pi j}{m}\right)-\frac{1}{2} \cos \left(\frac{2 \pi k}{n}\right) .
$$

Catatan: Hasil (9) ini sama persis dengan rumus yang diperoleh menggunakan persamaan karakteristik dari matriks Laplace, yang mana perhitungan ini melibatkan bentuk matriks sirkulan. Lebih lanjut lagi, pemilihan $P(A)$ ini mungkin akan menghasilkan graf torus bervariasi yang mungkin juga tidak saling isomorfik.

Selanjutnya dicari fungsi-fungsi eigen terkait dengan masing-masing $\lambda$. Untuk memudahkan ilustrasi, diambil $A=\left[\begin{array}{ll}8 & 0 \\ 0 & 6\end{array}\right]$, yang menghasilkan jajaran genjang representasi torus seperti pada gambar (10), (11), dan (12).

\subsubsection{Fungsi-fungsi Eigen}

Fungsi eigen yang terkait dengan nilai eigen $\lambda_{(j, k)}$ adalah $f_{\rho_{j, k}}\left(x_{1}, x_{2}, j\right)=\rho_{1}{ }^{x_{1}} \rho_{2}{ }^{x_{2}} u_{j}$, terdefinisi untuk setiap verteks $\left(x_{1}, x_{2}, j\right)$. Observasi fungsi-fungsi eigen ini dilakukan pada Graf torus lattice persegi panjang dengan mengambil periode dasar berupa persegi panjang yang memuat sebuah verteks, serta dipilih $A=\left[\begin{array}{ll}8 & 0 \\ 0 & 6\end{array}\right]$, sehingga $\triangle=48$, dan persamaan kunci yang diperoleh dari $P(A)$ adalah $\rho_{1}^{8} \rho_{2}^{0}=\rho_{1}^{0} \rho_{2}^{6}=1$.

Solusi dari persamaan kunci ini adalah $\mathbb{R}(A)=\left\{\left(e^{\frac{2 \pi i j}{8}}, e^{\frac{2 \pi i k}{6}}\right) \mid j=0,1,2, \ldots, 7, k=0,1,2, \ldots, 5\right\}$. Dengan melakukan subtitusi masing-masing solusi persamaan kunci ke persamaan masalah nilai eigen laplacian diperoleh 48 nilai eigen yang dirumuskan secara eksplisit, persisnya

$$
\lambda_{j, k}=1-\frac{1}{2} \cos \left(\frac{2 \pi j}{8}\right)-\frac{1}{2} \cos \left(\frac{2 \pi k}{6}\right)
$$

dengan $j=0,1,2, \ldots, 7, k=0,1,2, \ldots, 5$.

Beberapa perhitungan langsung untuk nilai eigen terurut yang diperoleh adalah

$$
0 \leq 0.146 \leq 0.146 \leq 0.25 \leq 0.25 \leq \ldots \leq 2
$$

Jelas 0 merupakan nilai eigen terkecil, yang diperoleh dengan subtitusi $j=k=0$ dan 0.146 adalah nilai eigen terkecil kedua, dengan multiplisitas aljabar 2, yang diperoleh dengan subtitusi $j=1,7$ dan $k=0$. Sedangkan nilai eigen terkecil ketiga 0.25 , diperoleh dari subtitusi $j=k=1$. 
Tabel 1: Nilai-nilai fungsi eigen pada tiap verteks terkait dengan $\lambda=0.25$

\begin{tabular}{|c|c|c|c|c|c|c|}
\hline$x_{1}, x_{2}$ & 0 & 1 & 2 & 3 & 4 & 5 \\
\hline 0 & 1 & $e^{\frac{\pi i}{3}}$ & $e^{\frac{2 \pi i}{3}}$ & -1 & $e^{\frac{4 \pi i}{3}}$ & $e^{\frac{5 \pi i}{3}}$ \\
\hline 1 & $e^{\frac{\pi i}{4}}$ & $e^{\frac{7 \pi i}{12}}$ & $e^{\frac{11 \pi i}{12}}$ & $e^{\frac{5 \pi i}{4}}$ & $e^{\frac{19 \pi i}{12}}$ & $e^{\frac{23 \pi i}{12}}$ \\
\hline 2 & $i$ & $e^{\frac{5 \pi i}{6}}$ & $e^{\frac{7 \pi i}{6}}$ & $-i$ & $e^{\frac{11 \pi i}{6}}$ & $e^{\frac{13 \pi i}{6}}$ \\
\hline 3 & $e^{\frac{3 \pi i}{4}}$ & $e^{\frac{13 \pi i}{12}}$ & $e^{\frac{17 \pi i}{12}}$ & $e^{\frac{21 \pi i}{12}}$ & $e^{\frac{\pi i}{12}}$ & $e^{\frac{5 \pi i}{12}}$ \\
\hline 4 & -1 & $e^{\frac{4 \pi i}{3}}$ & $e^{\frac{5 \pi i}{3}}$ & 1 & $e^{\frac{\pi i}{3}}$ & $e^{\frac{2 \pi i}{3}}$ \\
\hline 5 & $e^{\frac{5 \pi i}{4}}$ & $e^{\frac{19 \pi i}{12}}$ & $e^{\frac{23 \pi i}{12}}$ & $e^{\frac{\pi i}{4}}$ & $e^{\frac{7 \pi i}{12}}$ & $e^{\frac{11 \pi i}{12}}$ \\
\hline 6 & $-i$ & $e^{\frac{11 \pi i}{6}}$ & $e^{\frac{\pi i}{6}}$ & $i$ & $e^{\frac{5 \pi i}{6}}$ & $e^{\frac{7 \pi i}{6}}$ \\
\hline 7 & $e^{\frac{7 \pi i}{4}}$ & $e^{\frac{\pi i}{12}}$ & $e^{\frac{5 \pi i}{12}}$ & $e^{\frac{3 \pi i}{4}}$ & $e^{\frac{13 \pi i}{12}}$ & $e^{\frac{17 \pi i}{12}}$ \\
\hline
\end{tabular}

Nilai-nilai fungsi ini bernilai kompleks, jika disajikan dalam gambar yang setiap warna pada verteks menyatakan nilai argumen utama dari $f$ pada verteks tersebut, dapat dilihat pada gambar (10), (11), dan (12).

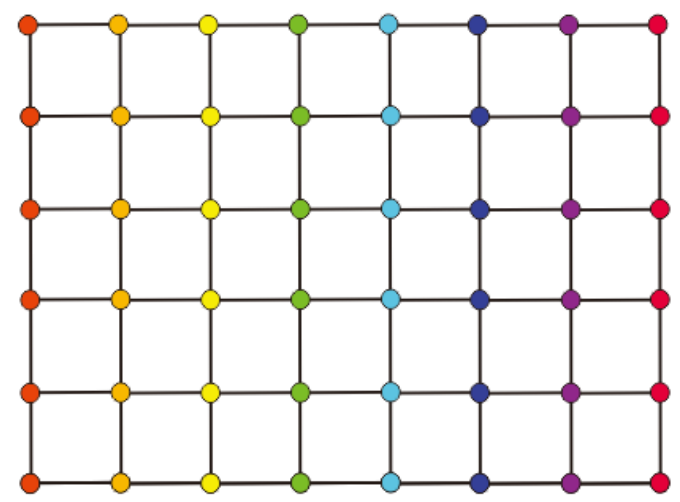

Gambar 10: Fungsi eigen pertama terkait dengan nilai eigen $\lambda=0.146$, pada graf lattice torus persegi panjang

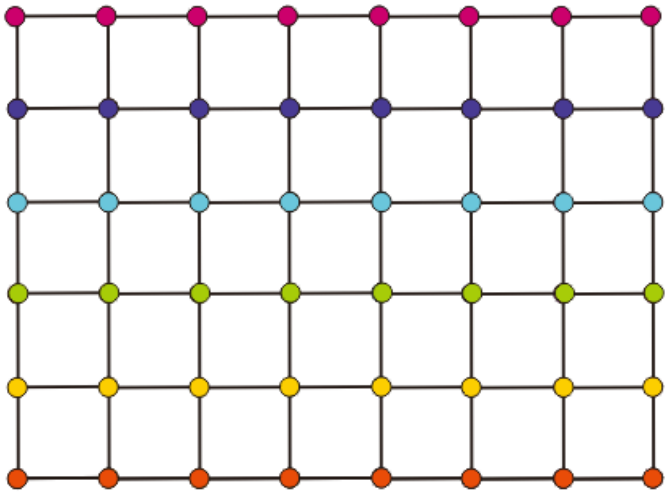

Gambar 11: Fungsi eigen kedua terkait dengan nilai eigen $\lambda=0.146$, pada graf lattice torus persegi panjang

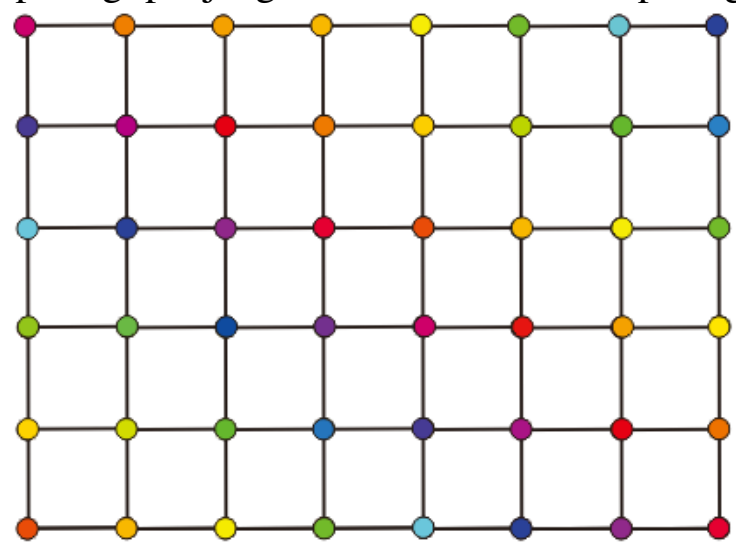

Gambar 12: Fungsi eigen pertama terkait dengan nilai eigen $\lambda=0.25$, pada graf lattice torus persegi panjang 


\subsection{Lattice Segitiga}

Lattice Segitiga dapat dipeoleh melalui modifikasi lattice persegi panjang, yakni dengan menambahkan rusuk" edge" diagonal pada setiap muka "rectangular face" lattice persegi panjang, seperti pada gambar 13. Meskipun cara ini menghasilkan graf lattice segitiga yang bukan merupakan segitiga sama sisi atau regular, namun karena graf yang dibahas di sini bukan graf berbobot, dan tak berarah, maka graf lattice segitiga yang dihasilkan merupakan graf yang isomorfik dengan lattice segitiga beraturan, seperti diilustrasikan pada gambar 14. Hal pertama yang selalu dilakukan sebelum

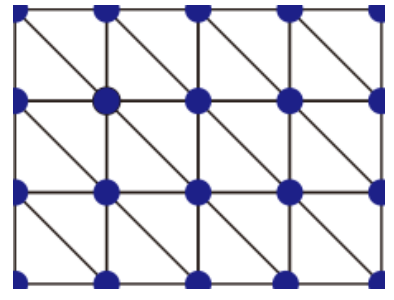

Gambar 13: Penambahan sisi diagonal

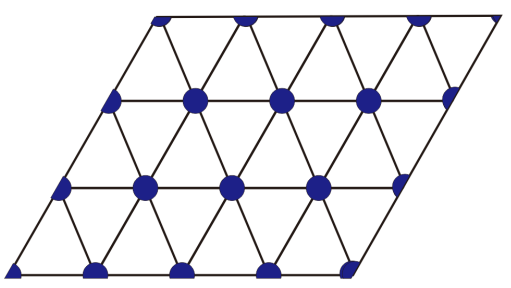

Gambar 14: Graf lattice segitiga yang dihasilkan

merumuskan masalah nilai eigen adalah memilih periode dasar dari graf periodik segitiga. Dalam hal ini, dipilih periode dasar sebagai berikut. Masalah nilai eigen Laplace setiap verteks adalah sebagai berikut.

$$
f(v)-\sum_{v^{\prime} \in N(v)} \frac{1}{6} f\left(v^{\prime}\right)=\lambda f(v)
$$

Selanjutnya dengan menggunakan anzats $f\left(x_{1}, x_{2}, j\right)=\rho_{1}{ }^{x_{1}} \rho_{2}{ }^{x_{2}} u_{j}$ dan melakukan subtitusi ke persamaan (10) diperoleh

$$
\lambda=1-\frac{1}{6}\left(\rho_{1}+\overline{\rho_{1}}+\rho_{2}+\overline{\rho_{2}}+\rho_{1} \overline{\rho_{2}}+\overline{\rho_{1} \overline{\rho_{2}}}\right) \text {. Misalkan } A=\left[\begin{array}{cc}
m & 0 \\
0 & n
\end{array}\right] \text {, maka diperoleh persamaan }
$$

kunci sebagai berikut

$$
\rho_{1}^{m} \rho_{2}^{0}=\rho_{1}^{0} \rho_{2}^{n}=1
$$

Solusi dari persamaan kunci ini sama persis dengan yang dihasilkan sebelumnya pada kasus lattice persegi panjang. Dengan melakukan subtitusi setiap solusi persamaan kunci ke ekspresi nilai eigen $\lambda$, diperoleh rumus eksplisit nilai eigen Laplacian untuk lattice segitiga sebagai berikut :

$$
\lambda_{(j, k)}=1-\frac{1}{3} \cos \left(\frac{2 \pi j}{m}\right)-\frac{1}{3} \cos \left(\frac{2 \pi k}{n}\right)-\frac{1}{3} \cos \left(\frac{2 \pi j}{m}-\frac{2 \pi k}{n}\right)
$$

dengan $j=0,1, \ldots, m-1, k=0,1, \ldots, n-1$. Rumus ini terlihat mirip dengan rumus nilai eigen pada lattice persegi panjang. Efek penambahan sisi diagonal berdampak secara morfologis pada perubahan rumus nilai eigen.

Selanjutnya secara khusus misalkan $m=8$ dan $n=6$, dengan menggunakan rumus eksplisit, diperoleh 48 nilai eigen yang secara ringkas adalah $0 \leq 0.195 \leq 0.195 \leq 0.276 \leq 0.276 \leq \ldots \leq 1.49$. Detail seluruh nilai eigen ini akan disajikan di akhir bersama dengan nilai eigen lattice persegi panjang pada sebuah grafik. Selanjutnya, plot fungsi-fungsi eigen terkait dengan nilai-nilai eigen awal disajikan pada gambar (15), (16), (17). 


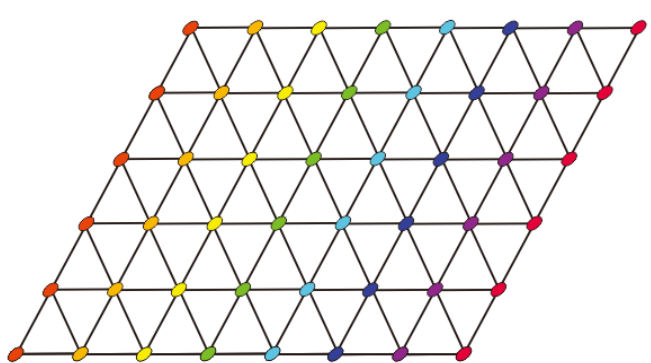

Gambar 15: Fungsi eigen pertama terkait dengan nilai eigen $\lambda=0.195$, pada graf lattice torus segitiga

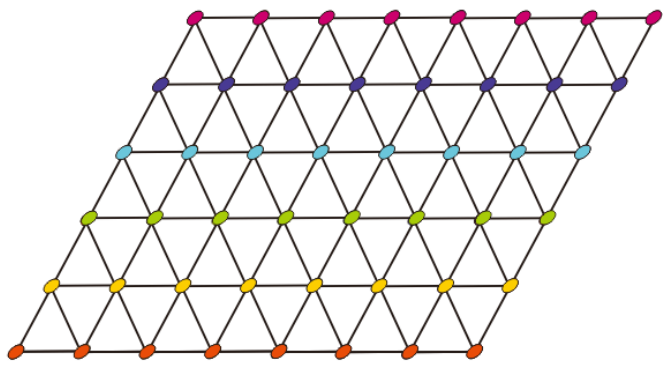

Gambar 16: Fungsi eigen kedua terkait dengan nilai eigen $\lambda=0.195$, pada graf lattice torus segitiga

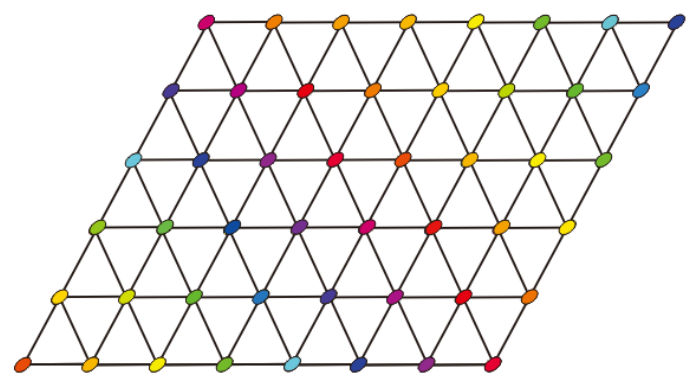

Gambar 17: Fungsi eigen pertama terkait dengan nilai eigen $\lambda=0.27$, pada graf lattice torus segitiga

\subsection{Lattice Segienam}

Graf lattice segienam, gambar(18), (19), juga disebut sebagai grid sarang lebah Honeycomb atau disebut juga cage 3,6, [8]. Graf lattice segienam ini merupakan dual graf dari graf segitiga dalam kemunculannya di torus. Oleh karenanya, graf lattice segienam ini dapat langsung diambil dari dual graf lattice segitiga. Tidak seperti dua graf yang dibahas sebelumnya, dalam periode dasar graf lattice segienam terdapat dua buah verteks, gambar (19), dengan demikian diperlukan dua buah persamaan masalah nilai eigen untuk dua buah verteks tersebut. Persamaan Masalah Nilai Eigen adalah sebagai berikut.

$$
f\left(v_{1}\right)-\sum_{v^{\prime} \in N\left(v_{1}\right)} \frac{1}{3} f\left(v^{\prime}\right)=\lambda f\left(v_{1}\right)
$$

dan

$$
f\left(v_{2}\right)-\sum_{v^{\prime} \in N\left(v_{2}\right)} \frac{1}{3} f\left(v^{\prime}\right)=\lambda f\left(v_{2}\right)
$$

Dengan melakukan subtitusi ansatz diperoleh persamaan matriks sebagai berikut.

$$
\left[\begin{array}{cc}
1 & -\frac{1}{3}\left(1+\overline{\rho_{1}}+\overline{\rho_{2}}\right) \\
-\frac{1}{3}\left(1+\rho_{1}+\rho_{2}\right) & 1
\end{array}\right]\left[\begin{array}{l}
f\left(v_{1}\right) \\
f\left(v_{2}\right)
\end{array}\right]=\lambda\left[\begin{array}{l}
f\left(v_{1}\right) \\
f\left(v_{2}\right)
\end{array}\right]
$$

Dengan langsung menyelesaikan persamaan karakteristik dari matriks Laplace sebelah kiri, diperoleh formulasi nilai Eigen sebagai berikut :

$$
\lambda=1 \pm \frac{1}{3} \sqrt{3+\rho_{1}+\overline{\rho_{1}}+\rho_{2}+\overline{\rho_{2}}+\rho_{1} \overline{\rho_{2}}+\overline{\rho_{1} \overline{\rho_{2}}}}
$$

Jika $A$ adalah matriks yang menyatakan representasi torus sama seperti dua graf yang sebelumnya dibahas, diperoleh persamaan kunci $\rho_{1}^{m}=\rho_{2}^{n}=1$. Dengan melakukan subtitusi langsung solusi persamaan kunci ke rumus $\lambda$ diperoleh rumus eksplisit nilai eigen sebagai berikut

$$
\lambda_{(j, k)}=1 \pm \frac{1}{3} \sqrt{3+2 \cos \left(\frac{2 \pi j}{m}\right)+2 \cos \left(\frac{2 \pi k}{n}\right)+2 \cos \left(\frac{2 \pi j}{m}-\frac{2 \pi k}{n}\right)}
$$




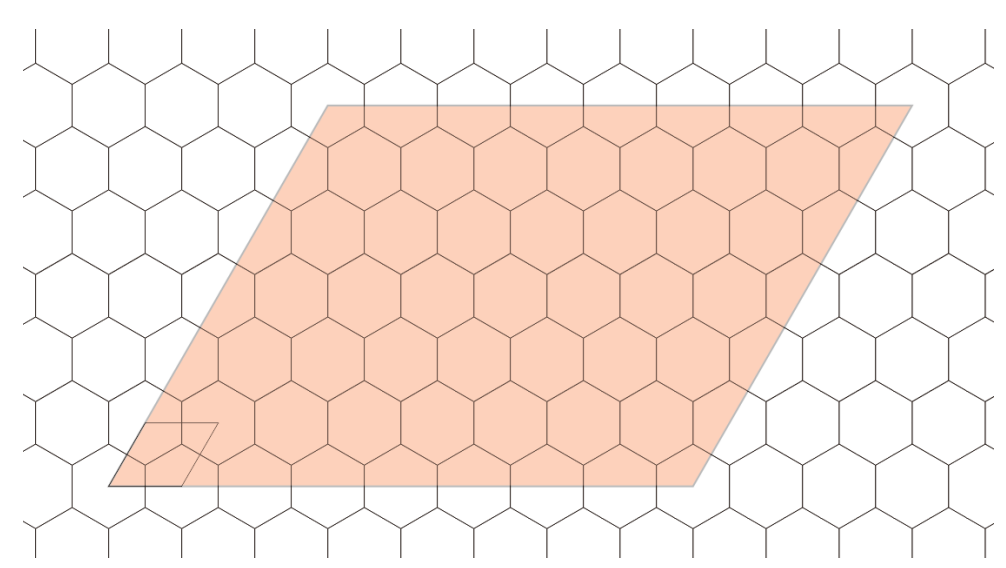

Gambar 18: Graf lattice segienam dan sebuah jajaran genjang representasi torus

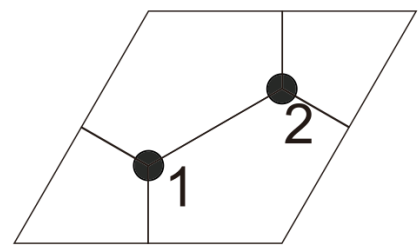

Gambar 19: Jajaran genjang periode dasar graf lattice segienam

,untuk $j=0,1,2, \ldots, m-1, k=0,1,2, \ldots, n-1$. Berbeda dengan rumus nilai eigen laplacian lattice persegi panjang dan segitiga, rumus (14) memberikan informasi bahwa pada graf lattice torus segienam dengan representasi torus $P(A)$, dengan $A=\left[\begin{array}{cc}m & 0 \\ 0 & n\end{array}\right]$ memiliki $2 \times m \times n$ buah nilai eigen. Hal ini sesuai dengan fakta bahwa $P(A)$ mengandung $2 \times m \times n$ verteks.

\subsection{Perbandingan Nilai-nilai Eigen pada Graf Lattice Torus: Persegipanjang, Segitiga, Segienam.}

Nilai-nilai eigen Laplacian dari Graf Lattice Torus persegipanjang, segitiga, dan segienam yang memuat $N$ buah verteks dapat diurutkan menjadi $0=\lambda_{0} \leq \lambda_{1} \leq \lambda_{2} \leq \cdots \leq \lambda_{N-1}$. Rumus-rumus eksplisit nilai eigen laplacian dari ketiga graf lattice ini telah berhasil didapatkan, yang berturut-turut ditunjukkan pada persamaan (9), (11), dan (14). Untuk melihat perilaku umum nilai-nilai eigen dari ketiga jenis graf lattice torus ini, dilakukan percobaan perhitungan nilai-nilai eigen dari beberapa graf torus dengan ukuran: $6 \times 4$ verteks, $8 \times 6$ verteks, $100 \times 50$ verteks, dan $500 \times 500$ verteks, gambar (20), (21), (22), (23). Khusus pada graf lattice segienam, graf yang memuat $m \times n$ verteks diperoleh dengan memilih representasi torus $P(A)$ dengan $A=\left[\begin{array}{cc}\frac{1}{2} m & 0 \\ 0 & n\end{array}\right]$.

Menurut hasil percobaan, terlihat bahwa untuk graf torus lattice persegi panjang dan segienam memiliki nilai eigen maksimum adalah 2 . Nilai eigen maksimum ini dicapai ketika $j=\frac{1}{2} m$ dan $k=\frac{1}{2} n$, untuk lattice persegipanjang. Sedangkan pada graf lattice segienam, nilai eigen 2 dicapai pada $j=k=0$. Hal yang berbeda terjadi pada graf lattice segitiga, nilai eigen maksimum laplacian ini kurang dari $1 \frac{2}{3}$. Batas atas nilai eigen ini dapat ditaksir dengan mudah pada rumus eksplisit nilai eigen lattice segitiga (11).

Perbandingan spektral gap dari ketiga graf lattice torus ini dibahas pada sub bab berikutnya. 


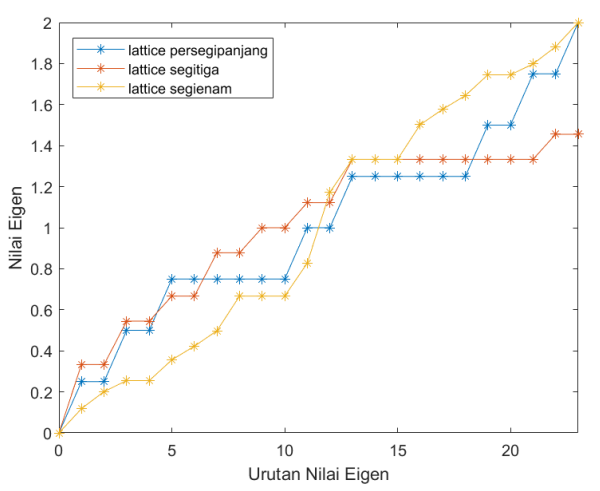

Gambar 20: Percobaan dengan 6x4 verteks

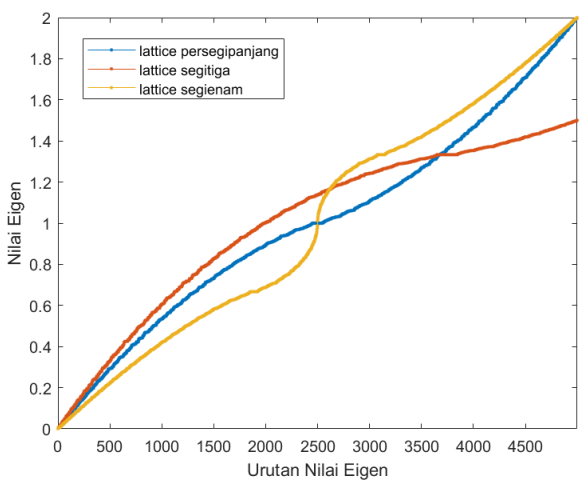

Gambar 22: Percobaan dengan 100x50 verteks

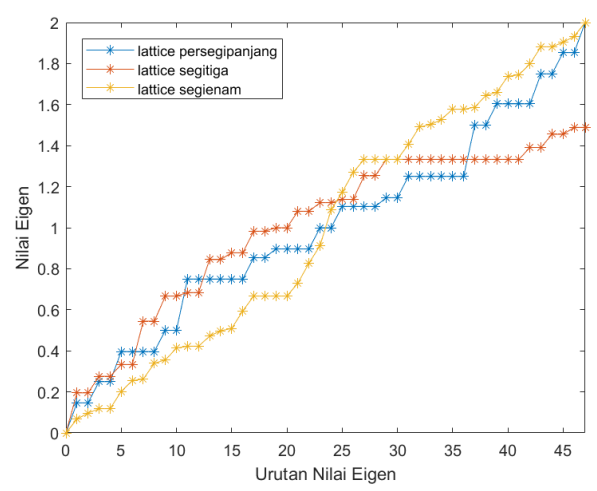

Gambar 21: Percobaan dengan 8x6 verteks

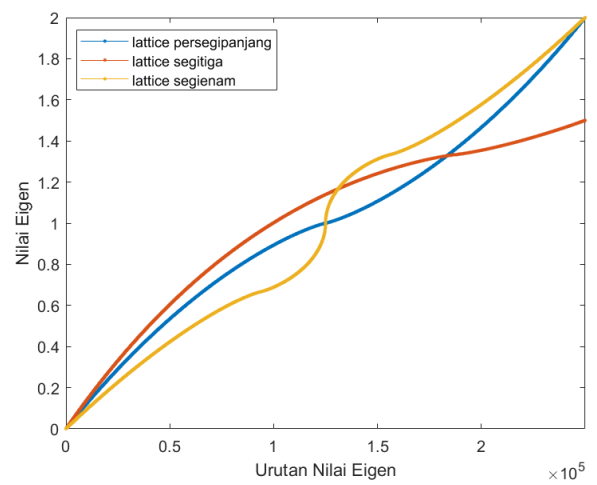

Gambar 23: Percobaan dengan $500 \mathrm{x}$ 500 verteks

\subsection{Perbandingan Spektral Gap}

Spektral gap laplacian merupakan jarak antara dua nilai eigen laplacian terkecil, $\lambda_{0}$ dengan $\lambda_{1}$, dinotasikan dengan $\delta=\lambda_{1}-\lambda_{0}$. Karena $\lambda_{0}$ senantiasa bernilai nol, maka spektral gap $\delta$ secara langsung adalah $\lambda_{1}$. Berdasarkan rumus eksplisit nilai eigen yang telah diperoleh, persamaan (9), (11), dan (14), untuk masing-masing jenis graf lattice torus, dapat diturunkan secara langsung rumus eksplisit spektral gap $\delta$ sebagai berikut

$$
\begin{aligned}
& \delta_{R}=\frac{1}{2}-\frac{1}{2} \cos \left(\frac{2 \pi}{\max \{m, n\}}\right) \\
& \delta_{T}=\frac{2}{3}-\frac{2}{3} \cos \left(\frac{2 \pi}{\max \{m, n\}}\right) \\
& \delta_{H}=1-\frac{1}{3} \sqrt{5+4 \cos \left(\frac{2 \pi}{\max \{m, n\}}\right)}
\end{aligned}
$$

dengan masing-masing $\delta_{R}, \delta_{T}$, dan $\delta_{H}$ berturut-turut adalah spektral gap untuk graf lattice torus persegi panjang, segitiga, dan segienam. Ketiga rumus spektral gap ini memberikan informasi bahwa semakin banyak verteks pada graf torus, maka ketiga spektral gap ini akan menuju 0 .

Khususnya, ketiga bilangan tersebut akan memenuhi ketaksamaan $0 \leq \delta_{H} \leq \delta_{R} \leq \delta_{T}$. Untuk nilai $m$ atau $n$ menuju tak hingga, akan berakibat bilangan $\delta_{T}$ menuju nol. 


\section{Kesimpulan}

Formulasi spektrum ketetanggaan graf torus yang dikembangkan sebelumnya telah berhasil diperumum dan diaplikasikan pada kasus operator laplace diskret pada graf torus. Beberapa contoh percobaan yang dikerjakan merupakan kasus lattice reguler, yakni representasi torus reguler yang dibangun secara langsung menggunakan masing-masing kelipatan vektor periode dasarnya. Persisnya A senantiasa berbentuk matriks diagonal. Formulasi ini dapat diterapkan untuk bentuk representasi torus $A$ yang lebih umum. Fungsi-fungsi eigen yang dihasilkan merupakan himpunan fungsi yang orthogonal, yang dapat pula dipandang sebagai basis untuk $l^{2}(P(A))$. Jika $A$ adalah matriks diagonal dengan elemen bilangan bulat, maka graf lattice persegi panjang, segitiga, dan segienam pada torus $P(A)$ mempunyai nilai-nilai eigen Laplacian yang disajikan pada tabel berikut.

Tabel 2: Rumus-rumus nilai Eigen Laplacain graf lattice torus

\begin{tabular}{|c|c|}
\hline Graf Torus & Rumus Nilai Eigen \\
\hline Lattice Persegi panjang & $\lambda_{(j, k)}=1-\frac{1}{2} \cos \left(\frac{2 \pi j}{m}\right)-\frac{1}{2} \cos \left(\frac{2 \pi k}{n}\right)$ \\
\hline Lattice Segitiga & $\lambda_{(j, k)}=1-\frac{1}{3} \cos \left(\frac{2 \pi j}{m}\right)-\frac{1}{3} \cos \left(\frac{2 \pi k}{n}\right)-\frac{1}{3} \cos \left(\frac{2 \pi j}{m}-\frac{2 \pi k}{n}\right)$ \\
\hline Lattice Segienam & $\lambda_{(j, k)}=1 \pm \frac{1}{3} \sqrt{3+2 \cos \left(\frac{2 \pi j}{m}\right)+2 \cos \left(\frac{2 \pi k}{n}\right)+2 \cos \left(\frac{2 \pi j}{m}-\frac{2 \pi k}{n}\right)}$ \\
\hline
\end{tabular}

Hasil konstruksi rumus ini sangat berguna dalam mempelajari Analisis Fourier pada graf periodik dan juga fitur-fitur utama dari sifat Random Walk pada graf torus.

\section{Referensi}

[1] F. R. Chung and F. C. Graham, Spectral graph theory. No. 92, American Mathematical Soc., 1997.

[2] F. R. Chung, "Laplacians of graphs and cheeger's inequalities," Combinatorics, Paul Erdos is Eighty, vol. 2, no. 157-172, pp. 13-2, 1996.

[3] O. Samuel, Y. Soeharyadi, and M. W. Setyabudhi, "The first two largest eigenvalues of laplacian, spectral gap problem and cheeger constant of graphs," in AIP Conference Proceedings, vol. 1913, p. 020014, AIP Publishing LLC, 2017.

[4] Y. Canzani, "Analysis on manifolds via the laplacian," Lecture Notes available at: http://www. math. harvard. edu/canzani/docs/Laplacian. pdf, 2013.

[5] D. I. Shuman, B. Ricaud, and P. Vandergheynst, "Vertex-frequency analysis on graphs," Applied and Computational Harmonic Analysis, vol. 40, no. 2, pp. 260-291, 2016.

[6] L. Lovász et al., "Random walks on graphs: A survey," Combinatorics, Paul erdos is eighty, vol. 2, no. 1, pp. 1-46, 1993.

[7] J. L. Gross and T. W. Tucker, Topological graph theory. Courier Corporation, 2001.

[8] P. E. John and H. Sachs, "Spectra of toroidal graphs," Discrete mathematics, vol. 309, no. 9, pp. 2663-2681, 2009. 